\title{
Who Wants To Be a Politician? Basic Human Values and Candidate Emergence in the United Kingdom
}

\author{
James Weinberg* \\ Department of Politics and International Relations, University of Sheffield, UK \\ ${ }^{\star}$ Corresponding author. E-mail: james.weinberg@sheffield.ac.uk
}

(Received 2 October 2018; revised 14 November 2019; accepted 16 December 2019; first published online 8 May 2020)

\begin{abstract}
Public faith in politicians and associated systems of governance is desperately low. At the same time, public opinion of politicians is characterized by a vernacular of psychological accusations pertaining to greed, self-interest and careerism. This article tests the verity of these claims by comparing quantitative data on the Basic Human Values (Schwartz 1992) of 106 UK Members of Parliament (MPs) and 134 unsuccessful parliamentary candidates with data collected from the British public in the seventh wave of the European Social Survey. It explores (a) how politicians differ psychologically from those they govern and (b) how personality characteristics such as basic values inform candidate emergence. The study finds that politics is a profession few 'ordinary' people care to enter. MPs attribute significantly more importance to SelfTranscendence values than the comparatively conservative population they govern, but the relative importance they ascribe to Power values seems to have an equally strong predictive effect on candidate emergence.
\end{abstract}

Keywords: political ambition; politicians; basic values; candidate emergence

Public judgements about politicians in recent years have been far from kind. The demonization of politicians has become a socially accepted phenomenon, fuelled by the media as well as the actions of a select few, and political science has done little to alter this narrative. Consequently, the 'bad faith model of politics' (Flinders 2012, 1) is now a pervasive and largely unchallenged feature of public as well as academic discourse (Norris 2011; cf. Corbett 2015). As Allen and Cairney $(2015,6)$ suggest, 'many of the complaints put at the door of the "political class" relate to Westminster politics and those with governing power or influence'. When talking of our national politicians, research and popular commentary on politics emphasize the careerist attitudes, self-serving behaviour and greed of our political elites (see, for example, Cohen 2011; Heidenheimer and Johnston 2002). These are all fundamentally psychological characteristics, but implicit assumptions about the personalities of our politicians are made without the methodological tools to link cause with effect, or to discriminate between individuals at different levels of governance or with different occupational or cultural backgrounds (cf. Weinberg 2019).

Clarke et al.'s (2018) recent analysis of Mass Observation (MO) data from 1937 onwards shows that criticisms of politicians per se have always been prevalent, but specific notions of 'the good politician' have moved away from an emphasis on competence and towards one on trust, authenticity and warmth. Clarke et al. (2018) argue that politicians' personal qualities have thus become the heuristic by which everyday judgements about the activities and performance of political institutions and systems are also formed (see also Whiteley et al. 2016). In line with perennial debates first raised by Easton (1965), these specific appraisals of moral malaise in 
elite politics have gravely affected diffuse public support for broader political processes and institutions (see also Jennings, Stoker and Twyman 2016). Yet whereas prior studies focus on the public and demonstrate the content or importance of these psychological claims for anti-politics (see also Allen 2018), they do not test the reality of these abstractions.

In this article, I directly address this gap in the study of political elites by examining the Basic Human Values (Schwartz 1992) of national politicians in the UK. Unique self-report survey data on the basic values of 106 UK Members of Parliament (MPs) and 134 unsuccessful parliamentary candidates are analysed alongside comparative data for the British public extracted from the seventh round of the European Social Survey (ESS 2014/2015). The data are used to answer two key research questions:

RQ1: Are there psychological differences between politicians and the general public?

RQ2: To what extent do personality characteristics such as basic values affect self-selection to elite politics?

Through empirical investigation of these questions, this article makes two significant contributions to the political science literature. First, this study is the first of its kind to extract selfreport data on the basic values of national politicians in the UK, and among the first to analyse how these specific personality characteristics contribute to the highest form of political selfselection in a liberal democracy. Secondly, I cover new ground in giving empirical weight to existing debates in the study of parliaments, legislatures and anti-politics that have, for some time, passed judgement on the psychological qualities of governors and the governed.

\section{'Only in it for themselves!'}

The question of why individuals choose a political career, and what separates them from those who do not and never would, has troubled political scientists researching political ambition and recruitment for over 60 years. The rational choice paradigm that dominates this literature in political science draws from Schlesinger's (1966) seminal Ambition and Politics, which framed ambition as a response to opportunity structures in the political environment. Subsequent studies of the effects of, for example, term limits, legislative professionalization, party congruence with constituents, and party recruitment criteria and procedures have dominated a largely US-centric literature on political ambition (for example, Kazee 1994; Maestas et al. 2006; Moncrief, Squire and Jewell 2001). Rational choice explanations of candidate emergence put forward by Schlesinger and his disciples treat all (eligible) members of the public as equally desirous of candidacy should they be faced with the right political opportunity structure. This research agenda has burnished a model for the micro-analysis of politicians' decisions inter alia to remain in their elected position (static ambition), to seek higher office (progressive ambition) or to step down/retire before an election (discrete ambition).

More recent studies in the US (Lawless and Fox 2005; Lawless and Fox 2010) and the UK (Allen and Cutts 2018) have shown, however, that a series of individual-level demographic and socio-economic variables exert substantial effects on the political ambition of eligible candidates. Both Lawless' (2012) research with longitudinal data from the American Citizen Political Ambition Panel Study and Allen and Cutts' (2018) survey of 10,000 citizens in the UK found, for example, that men were far more likely than women to consider running for office at all; the highly educated were more likely to consider themselves qualified for office; and individuals with higher incomes and lower levels of political cynicism were also more likely to consider a candidacy.

In this context, it seems plausible that rational choice accounts of candidate emergence overestimate the discrete impact of political opportunity structures and cost/benefit analyses by 
aspiring politicians. Instead, Lawless $(2012,19)$ argues that the initial decision to run for political office should be traced back to 'nascent' ambition, which she believes is a pre-requisite for Schlesinger's expressive ambition and grounded in socio-demographics, familial and professional socialization, and political attitudes. When taken together, these studies not only testify to the hyper-selectivity of recruitment to national politics (fewer than 10 per cent of participants in Allen and Cutts' survey had considered running for political office or would do in the future), but also suggest that supply-side variables associated with the professionalization of politics (for example, salaries, diverse offices and career paths) may not be as important as demand-side variables (individual differences and experiences).

Whiteley and Seyd's (2002) earlier panel study of Labour and Conservative party members goes further in unpicking this contested area of research. They test four different models to explain such high-intensity participation as running for elected office: civic voluntarism (including socio-economic and resource variables), social-psychological (including measures of personal efficacy, social norms or perceptions of attitudes towards parties and their members, and affective attachments to parties), rational choice (including the perceived costs of participation, the collective benefits associated with party policies, selective incentives or private returns from involvement, and ideological congruence), and general incentives (combining the former two). They regress a series of scales of high-intensity participation on each of these models and find that, on average, the civic voluntarism model raises important findings but performs worse than the others, and that the rational choice model performs much better when combined with the social-psychological model. In their longitudinal analysis, the effects of cost perception drop out (implying that they may only be useful predictors in the short term) but the social-psychological indicators remain highly significant.

Whiteley and Seyd's (2002) study is limited insofar as (a) the data are drawn entirely from party members and therefore privilege an already self-selecting group, and (b) the socialpsychological model focuses upon hyper-specific attitudes and opinions about party-specific issues that do not drill down into the effects of more base-level cognitive and biological individual differences such as those rooted in personality (see Greenstein 1992). However, the data are instructive for illustrating the follies of single-theory studies that prioritize one normative or empirical strategy over all others. Therefore, I propose a model of candidate emergence that accounts for the role of personality as one key antecedent in an individual's decision about whether to run for political office (Figure 1). As such, political opportunity structures should not be taken as the catalysts of ambition, but rather the means by which individuals might service a variety of 'ambitions' that are grounded in individual personality differences. The next section explores these personality characteristics.

\section{Personality Traits and Candidate Emergence}

The extant research base on the role of personality in politics has gathered pace in recent years (Caprara and Silvester 2018; Dietrich et al. 2012). However, studies of personality in leadership particularly those that gather representative self-report data on elected politicians' personalities are unique (cf. Wyatt and Silvester 2018; Zaccaro 2007). That said, a handful of studies have, in recent years, managed to extract self-report data on the personality traits of politicians in the US, Germany, Italy, Denmark, Belgium and Canada (e.g. Best, 2011; Caprara et al., 2010; Hanania 2017; Norgaard and Klemmensen 2018; Scott and Medeiros 2019).

Personality traits are quantifiable psychological qualities that are, generally, normally distributed in the population (Caprara and Silvester 2018). Research into traits has been made more accessible by the widely used taxonomy of traits known as the 'Big Five' or the Five Factor Model. This taxonomy includes five basic traits: Extraversion (sociability, vigour, dynamism), Agreeableness (honesty, sincerity, loyalty), Neuroticism (impulsiveness, emotional stability), Conscientiousness (diligence, precision, reliability), and Openness to Experience (imagination, 


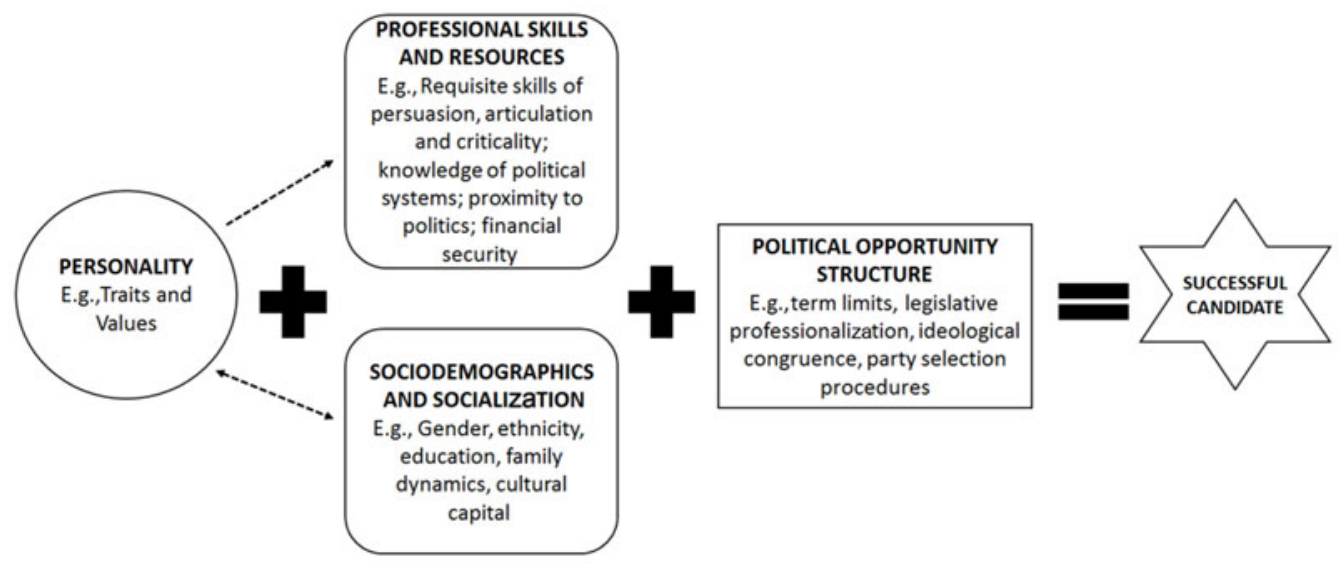

Figure 1. A comprehensive model of candidate emergence

Note: the single-direction dotted line between personality and professional skills reflects the likelihood that individuals will be attracted to jobs that increase the possibility of pursuing motivational goals associated with their most important basic values. The multidirectional line between personality and socio-demographics reflects the reciprocity between basic values and child/adolescent socialization experiences that are likely to be shaped by variables such as gender and ethnicity (Schwartz 1992).

creativity, innovation). In his study of German legislators in the European, federal and state parliaments, Best (2011) found that politicians scored higher than the German population for Extraversion and Openness, but lower for Neuroticism, Agreeableness and Conscientiousness. Working with a sample of elected officials in Italy, Caprara et al. (2010) found that politicians scored higher than the general population in Extraversion and lower in Neuroticism but, unlike Best's study in Germany, Italian politicians scored higher for Agreeableness and only female legislators scored higher for Openness.

Comparable studies in the United States have shown that state legislators score higher for Conscientiousness, Agreeableness and Extraversion than the American population (Hanania 2017), while Nørgaard and Klemmensen (2018) find that Danish MPs score higher for Extraversion, Emotional Stability (the inverse of Neuroticism), Conscientiousness and Agreeableness than their compatriots. However, the effects of Emotional Stability, Openness and Conscientiousness dropped out when Nørgaard and Klemmensen matched their elite and mass samples on gender and education. Taken together, these studies testify to a process of psychological self-selection to elite politics in a number of Western liberal democracies. In particular, politics as a vocation appears to attract people who are energetic, assertive and action oriented (Extraversion). At the same time, these studies of the Big Five in politics have produced a number of contradictory results. While these inconsistencies may be due to cultural differences, discrepancies in the different questionnaire batteries used by the researchers, or even the confounding effects exerted by different electoral systems, Nørgaard and Klemmensen (2018) argue that research in this field is far more informative at the aspect level of these traits. There is a case then for a more nuanced approach to this problem that uses a theory and/or measure of personality with both versatility and precision at a more fine-grained level than the Big Five.

\section{Basic Values}

As an academic concept, personality is broad and multifaceted. As with any interdisciplinary study, it is therefore vital to be precise about the terms being employed. In this article I examine the basic values of politicians to ascertain the effect of personality characteristics on candidate emergence. In focusing on basic values, I examine a functional base of personality that is both 
more distal than perceptions and beliefs and more proximal than the Big Five personality traits (Greenstein 1992). Basic values have been operationalized as core facets of personal identity (Hitlin 2003) and used to explain a variety of external social and political behaviours (for example, Schwartz et al. 2010). As such, '[v]alues are a central personality construct and the importance of studying them has been well established' (Sandy et al. 2017, 1).

Basic values are cognitive representations of desirable, trans-situational goals that act as guiding principles in the life of a person or group. Schwartz's dominant taxonomy of Basic Human Values organizes ten lower-order values into a circumplex continuum according to their conflict and congruence with one another (see Schwartz et al. 2010, 425). On one orthogonal, values are collated for their shared expression of Openness to Change (Self-Direction, Hedonism and Stimulation values) and in opposition to Conservation values (Tradition, Conformity and Security values). The former group stresses receptivity to change as well as independent thought, feeling and action, whereas the latter emphasizes submissive self-restriction, a desire for stability and the preservation of traditional practices. The second orthogonal juxtaposes Self-Transcendence values (Universalism and Benevolence values) with Self-Enhancement values (Power and Achievement values). The former group encourages acceptance of others as equals and regard for their welfare, while the latter prioritizes the pursuit of personal success and dominance over material and human resources (Schwartz 2010). Research in personality studies has shown that basic values mediate the effect of traits in behavioural analysis (Caprara et al. 2009), while people also tend to find their own basic values more desirable than their traits and express less of a wish to change them (Roccas et al. 2014). Their inherent desirability makes basic values uniquely powerful as a motivator of behaviour and, consequently, incredibly useful as a way for social scientists to explain situated agency such as political ambition and candidate emergence.

Basic values have a number of external correlates that make possible contestations about their hypothetical impact on political ambition. On the one hand, a number of prosocial behaviours and so-called calling professions have been positively associated with Self-Transcendence values and negatively linked to Conservation and Self-Enhancement values (Arieli, Sagiv and Cohen-Shalem 2016; Daniel et al. 2015; Twenge et al. 2007). Meta-analyses of basic values and the Big Five have also shown associations between Self-Transcendence values and the personality trait Agreeableness (Parks-Leduc, Feldman and Bardi 2015, 13). Given the research from Italy and the US reviewed above, as well as the central service orientation of politics qua representation, I expect that UK MPs will score higher on Self-Transcendence values (Universalism and Benevolence) than those they govern, and that these values will consequently play an important role in candidate emergence (Hypothesis 1).

On the other hand, the studies reviewed above also showed that politicians in comparative contexts score higher on Extraversion, which has been shown to correlate with SelfEnhancement values and Openness to Change values. Self-Enhancement values, in particular, have been positively associated in prior research with 'career' professions where 'enterprising' agendas involve managing subordinates towards a set of organizational or self-specific targets (Gandal et al. 2005; Sagiv 2002). Given that (a) UK parliamentary politics is characterized by intense conflict between tribal political parties and hierarchies of power, and (b) politicians who succeed will need to be decisive, strategic and able to cope in the limelight of a 24-hour news media, then I also anticipate that Self-Enhancement values (Achievement and Power) will play a crucial role in differentiating MPs from the rest of the UK population (Hypothesis 2).

\section{Methods}

The focus of this article is on psychological self-selection to elite politics in the UK. It offers the first in-depth quantitative analysis of MPs' basic values in order to assess (a) the types of people sitting in Westminster and the extent to which they differ from the public and (b) the accuracy of broader psychological claims in the popular and academic press based on careerism and 
self-interest. In answering these questions, this article fills a significant gap in the research base by examining the role that basic values may play in predisposing certain individuals to consider a career in British politics.

\section{Data Collection}

The findings presented in this article are based, in the first instance, on a three-phase tailored design study of politicians in the UK Parliament that ran from November 2016 to May 2017. MPs were approached sequentially via post, email and phone, as well as through advocates recruited in the participation process. This process was repeated. In order to bolster the size of the sample, this data collection process was followed up with a single wave of targeted email correspondence to recently retired MPs who are still active in Parliament as members of the House of Lords. This produced a diverse sample of 106 MPs (85 current, 21 former) by gender, party, age, status and length of service (see Table 1). This response rate of 13 per cent+ (considering current MPs only) compares favourably to studies of political elites in Italy (10 per cent, Caprara et al. 2010) and the United States (4 per cent, Hanania 2017). The survey itself was designed in two main sections with a total of thirty questions. The first section measured participants' basic values, while the second section of the survey asked MPs to provide basic demographic information on age, gender, education and occupational experience, as well as information on specific political behaviours, attitudes and ideologies.

In early 2019, an identical measure of basic values was included in a longer survey project conducted with all political candidates who had stood in local (council) elections, national (Westminster Parliament) elections, or international (European Parliament) elections between May 2010 and May 2019, and who made their contact details available to the Electoral Commission at the time of standing. ${ }^{1}$ This survey was part of a larger project on the policy attitudes and mental wellbeing of politicians, but it produced an additional dataset on the basic values of 134 unsuccessful parliamentary candidates. ${ }^{2}$ A comparative dataset for the basic values of the British public $(n=2,264)$ was extracted from the seventh round of the European Social Survey (ESS 2014/2015). ${ }^{3}$ Although data from MPs, candidates and the public were collected in different years, previous studies of basic values have shown that they are incredibly stable over time and across situations (Sagiv et al. 2017). It is therefore highly unlikely that these sample populations changed their values between these periods of data collection.

\section{Measures}

Data on MPs' basic values were gathered using a shortened version of the 40-item Portrait Values Questionnaire (PVQ; Schwartz et al. 2001). The PVQ emphasizes context-free thinking and contains short verbal portraits of individuals, gender-matched with the respondent. For each portrait, participants respond to the question 'How much like you is this person?' using a six-point Likert scale that ranges from 'very much like me' to 'not like me at all'. The shortened measure - the Twenty Item Values Inventory (TwIVI) - contains two portraits for each of the ten motivationally distinct types of value (see section 'Basic Values'). The TwIVI can be completed in less than 5

\footnotetext{
${ }^{1}$ Participants were identified through the Democracy Club database of political candidates, which contains details of all consenting individuals who have participated as a candidate in an election in the UK since 2010. More than 11,000 of these participants (total database $=70,000+$ ) provided contact email addresses to the Electoral Commission. The database is free to use so long as the Democracy Club are acknowledged in any research outputs that arise (CC-BY license). The database is maintained in line with current GDPR regulations. The survey was fielded through the online platform Qualtrics to each political candidate who was contactable in this database. They received an email containing comprehensive information about the project, the survey and the security of their data, and all responses were gathered on Qualtrics anonymously.

${ }^{2}$ Ethics approval for all waves of data collected was granted in advance by the University of Sheffield's Department of Politics (ref.008585; ref.027158).

${ }^{3}$ Data were downloaded online at: http://www.europeansocialsurvey.org/download.html?file=ESS7e02_1\&y=2014.
} 
Table 1. Descriptive data for samples of elected MPs, unsuccessful parliamentary candidates and the British public

\begin{tabular}{|c|c|c|c|c|}
\hline & $\begin{array}{l}\text { MP Sample } \\
\qquad(\mathrm{N}=106)\end{array}$ & $\begin{array}{l}\text { House of Commons } \\
\qquad(\mathrm{N}=650)\end{array}$ & $\begin{array}{l}\text { Unsuccessful candidates } \\
\qquad(N=134)\end{array}$ & $\begin{array}{l}\text { ESS sample }\left(7^{\text {th }} \text { round }\right) \\
(\mid N=2,264)\end{array}$ \\
\hline \multicolumn{5}{|l|}{ Gender } \\
\hline Male & $67 \%$ & $68 \%$ & $72 \%$ & $45 \%$ \\
\hline Female & $33 \%$ & $32 \%$ & $28 \%$ & $55 \%$ \\
\hline Age (mean) & 55 yrs & $51 \mathrm{yrs}$ & 53 yrs & 52 yrs \\
\hline Length of Service: (mean) & 9.6 yrs & $9.4 \mathrm{yrs}$ & $\mathrm{N} / \mathrm{A}$ & $\mathrm{N} / \mathrm{A}$ \\
\hline \multicolumn{5}{|l|}{ Party ${ }^{\star}$} \\
\hline Labour & $47 \%$ & $40 \%$ & $16 \%$ & $33 \%$ \\
\hline Conservative & $31 \%$ & $49 \%$ & $8 \%$ & $35 \%$ \\
\hline Liberal & $5 \%$ & $2 \%$ & $19 \%$ & $15 \%$ \\
\hline \multicolumn{5}{|l|}{ Democrat } \\
\hline SNP: & $9 \%$ & $5 \%$ & $15 \%$ & $3 \%$ \\
\hline Other & $8 \%$ & $4.3 \%$ & $42 \%$ & $14 \%$ \\
\hline $\begin{array}{l}\text { Frontbench } \\
\text { (Over career) }\end{array}$ & $19 \%(63 \%)$ & $42 \%$ ** & $\mathrm{N} / \mathrm{A}$ & $\mathrm{N} / \mathrm{A}$ \\
\hline
\end{tabular}

Note: descriptive statistics for the House of Commons (as of the 2017 general election) are included for comparison. ${ }^{*}$ ESS scores relate to votes cast in the 2010 general election; ${ }^{\star *}$ Based on the four most represented parties in Westminster at the time of sampling.

minutes and has already proven capable of fully recapturing the psychometric properties of the longer PVQ-IV in large-N comparative populations (Sandy et al. 2017). Example portraits include:

(1) $\mathrm{S} /$ he believes $\mathrm{s} /$ he should always show respect to his/her parents and to older people. It is important to him/her to be obedient (Conformity values);

(2) S/he thinks it is important that every person in the world be treated equally. S/he believes everyone should have equal opportunities in life (Universalism values);

(3) Getting ahead in life is important to him/her. S/he strives to do better than others (Achievement values).

For each value, participants' scores are centred on his/her mean rating of all items on the scale in order to correct for individual differences in scale use. Cronbach alpha reliability coefficients for the four higher-order values in the sample of elected MPs are 0.718 for Conservation, 0.666 for Self-Transcendence, 0.824 for Openness to Change and 0.870 for Self-Enhancement (alphas for the ten lower-order values range from 0.443 for Security to 0.880 for Achievement, with seven values scoring higher than 0.6). These scores meet acceptable levels for multivariate research with psychometric surveys (Hair et al. 2006).

The TwIVI was also administered to a random sample of 134 unsuccessful parliamentary candidates. Although samples of elected MPs and unsuccessful parliamentary candidates completed identical copies of the TwIVI, they did so at different points in time. There is also, as evidenced in Table 1, some variation in the partisan/ideological and demographic composition of the groups. The sample of unsuccessful parliamentary candidates includes, for example, a considerable number of Green Party and UKIP (United Kingdom Independence Party) members who are not represented in the sample of elected MPs. Therefore, I check for measurement equivalence across the two samples using a series of nested multiple group confirmatory factor analyses (for a discussion of best practice, see Putnick and Bornstein 2016). In this instance, survey data collected on the basic values of politicians in the two samples achieves both metric and scalar invariance. ${ }^{4}$

\footnotetext{
${ }^{4}$ Model 1 (Unconstrained) $-\chi^{2}(\mathrm{df})=423.989$ (250), CFI $=0.900$, RMSEA $=0.076$; Model 2 (Constrained factor loadings) $\chi^{2}(\mathrm{df})=427.735(260), \mathrm{CFI}=0.904$, RMSEA $=0.073$; Model $1 / 2$ comparison $-\Delta \chi^{2}(\Delta \mathrm{df})=3.746(10), \Delta \chi^{2}$ significance $=\mathrm{p}<$ $0.958, \Delta \mathrm{CFI}=0.004, \Delta \mathrm{RMSEA}=0.003$, Decision $=$ ACCEPT METRIC INVARIANCE; Model 3 (Constrained factor loadings
} 
A brief twenty-one item version of the PVQ is also used in the European Social Survey (PVQ-21; Schwartz 2003). It provides a rich source of data on the basic values of general population samples and therefore continues to inform large-scale comparative research (see, for example, Piurko, Schwartz and Davidov 2011). Although the PVQ-21 and the TwIVI vary in some of their item descriptors, both surveys are designed to measure the same theoretical framework and their items are derived from common questions in the longer PVQ-40. The two surveys share extremely similar properties (Sandy et al. 2017). Using the same derivation $(n=38,049)$ and evaluation $(n=29,143)$ samples, Sandy et al. (2017) have shown, for example, that the TwIVI and the PVQ-21 exhibit high convergent validity $(\mathrm{r}>0.9)$ and external validity (both measures matched in excess of 80 per cent of PVQ-40 correlates).

\section{Analysis}

The observable nature of democratic politics makes possible a host of hypothetical contestations about the personal characteristics required, expected or assumed of politicians. I test these claims with a unique study of MPs' basic values. This section compares centred mean scores for the basic values of MPs and their electors (including a matched sample of the public), and closely examines the nature of political ambition by assessing the predictive power of basic values when it comes to self-selection in British politics.

\section{RQ1: Are there psychological differences between politicians and the general public?}

A comparison of basic value scores in the elite sample of elected MPs and the ESS general population sample provides strong support for the suggestion that personality influences self-selectivity in political recruitment in the UK. The centred mean scores (MRAT) for the basic values of elected MPs and the public differ across eight out of ten lower-order values to high degrees of statistical significance (Table 2, Figure 2). The results of independent sample t-tests with Bonferroni corrections suggest, for example, that MPs are significantly more driven by motivations to care for those around them and support those they know personally (higher scores for Benevolence: $\mathrm{t}(2,257)=$ $4.26, \mathrm{p}<0.001$; support for Hypothesis 1 ); they are significantly more driven by originality and a desire for new experiences (higher scores for Openness to Change values: $t(2,257)=3.49$, $\mathrm{p}<$ $0.001)$; and they are significantly less motivated to preserve traditions (Tradition values: $t(2,257)$ $=-10.56, \mathrm{p}<0.001)$ or to secure stability in their own lives or society (Security values: $\mathrm{t}(2,257)$ $=-8.71, \mathrm{p}<0.001)$. Given that Bonferroni corrections are among the most conservative multiplecomparison corrections, and by implication deflate significance levels to reduce the risk of Type I errors, the size and statistical significance of the test statistics reported in Table 2 are impressive. The data point to specific personality factors in the selection and self-selection of UK MPs.

To test the robustness of these results, Table 2 also reports the results of additional t-tests between MPs and a case-controlled ESS sample matched for age, gender, education and partisanship. ${ }^{5}$ The effects of Universalism and Self-Direction values drop out in the matched comparison. Given that these values correlate strongly and positively with education (Schwartz 2005), it is perhaps unsurprising that these differences disappear when MPs are compared to highly educated members of the public (87 per cent of the MP sample held graduate or postgraduate degrees). Yet even when compared to this matched sample, statistically significant differences remain between MPs and their electors across six basic values. Given that differences in personality traits disappeared when Nørgaard and Klemmensen (2018) matched their sample of Danish MPs and

and item intercepts $)-\chi^{2}(\mathrm{df})=436.075(270)$, CFI $=0.905$, RMSEA $=0.072$; Model $2 / 3$ comparison $-\Delta \chi^{2}(\Delta \mathrm{df})=8.34(10)$, $\Delta \chi^{2}$ significance $=\mathrm{p}<0.596, \Delta \mathrm{CFI}=0.001, \Delta \mathrm{RMSEA}=0.001$, Decision $=$ ACCEPT SCALAR INVARIANCE.

${ }^{5}$ For partisanship, MPs and citizens were matched according to whether they represented or voted for political parties that are broadly aligned on the left or right. This control was included to account for the over-representation of Labour MPs in the elite sample. 
Table 2. Mean differences between the Basic Human Values of UK MPs $(N=106)$ and a representative sample of the British population

\begin{tabular}{|c|c|c|c|}
\hline \multicolumn{2}{|l|}{ Basic Human Values } & \multicolumn{2}{|c|}{ Centred mean scores (MRAT) } \\
\hline (Four Factor) & (Ten Factor) & MP/Public = MRAT difference & $\begin{array}{l}\text { MP/Public = MRAT difference } \\
\text { [matched sample, } \mathrm{N}=212]\end{array}$ \\
\hline 1. Self-Transcendence & $\begin{array}{l}\text { 1. Benevolence } \\
\text { 1. Universalism }\end{array}$ & $\begin{array}{l}1.13(0.07) / 0.85(0.01)=0.28^{\star \star \star} \\
0.88(0.09) / 0.64(0.01)=0.23^{\star \star \star}\end{array}$ & $\begin{array}{l}1.15(0.07) / 0.82(0.06)=0.33^{* * *} \\
0.87(0.09) / 0.85(0.07)=0.02\end{array}$ \\
\hline 2. Openness & $\begin{array}{l}\text { 2. Self-Direction } \\
\text { 2. Stimulation } \\
\text { 2. Hedonism }\end{array}$ & $\begin{array}{l}0.63(0.08) / 0.47(0.02)=0.17^{*} \\
-0.14(0.08) /-0.64(0.02)=0.50 * \star * \\
-0.49(0.08) /-0.41(0.02)=-0.08\end{array}$ & $\begin{array}{l}0.64(0.08) / 0.55(0.08)=0.09 \\
-0.14(0.08) /-0.69(0.09)=0.55 * \star \star \\
-0.49(0.08) /-0.51(0.08)=0.02\end{array}$ \\
\hline 3. Self-Enhancement & $\begin{array}{l}\text { 3. Achievement } \\
\text { 3. Power }\end{array}$ & $\begin{array}{l}-0.48(0.09) /-0.56(0.02)=0.08 \\
-0.47(0.08) /-1.08(0.02)=0.61 \text { *** }\end{array}$ & $\begin{array}{l}-0.48(0.09) /-0.43(0.09)=-0.04 \\
-0.47(0.08) /-1.07(0.09)=0.63 * \star \star\end{array}$ \\
\hline 4. Conservation & $\begin{array}{l}\text { 4. Security } \\
\text { 4. Conformity } \\
\text { 4. Tradition }\end{array}$ & $\begin{array}{l}-0.15(0.09) / .55(0.02)=-0.70^{\star \star \star} \\
0.02(0.09) /-0.19(0.02)=0.22^{\star} \\
-0.93(0.13) / 0.05(0.02)=-0.98^{\star \star \star}\end{array}$ & $\begin{array}{l}-0.15(0.09) / 0.36(0.07)=-0.54^{\star \star \star} \\
0.02(0.09) /-0.27(0.09)=0.28 * \\
-0.93(0.13) /-0.05(0.09)=-0.91 * \star \star\end{array}$ \\
\hline
\end{tabular}

Note: $\mathrm{n}=2,154$. Two-tailed significance: Standard errors in parentheses. ${ }^{\star} \mathrm{p}<0.05 ;{ }^{* \star} \mathrm{p}<0.01 ;{ }^{\star \star \star}{ }_{\mathrm{p}}<0.001$

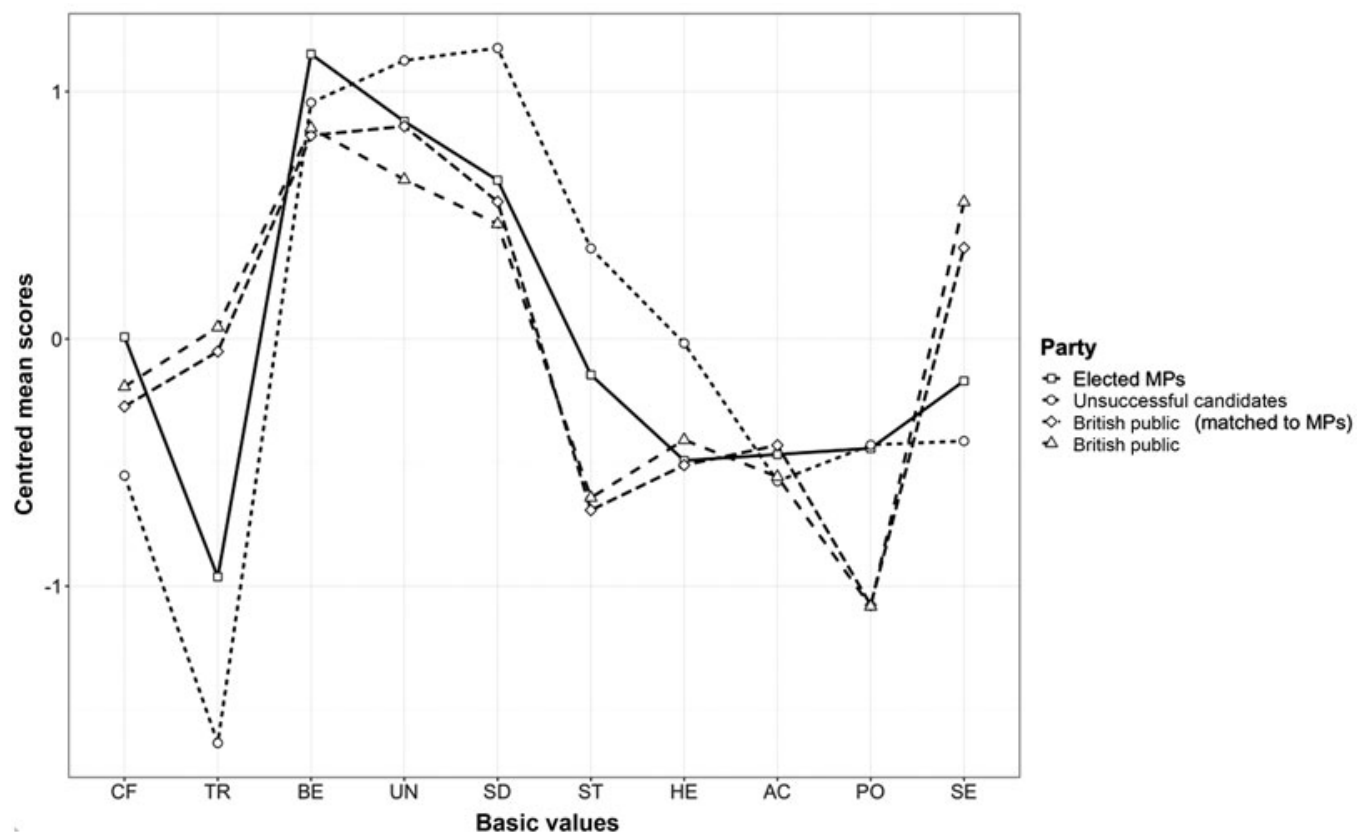

Figure 2. Comparison of centred mean scores for the basic values of elected MPs, unsuccessful parliamentary candidates and the British public

Note: $\mathrm{CF}=$ Conformity values; $\mathrm{TR}=$ Tradition values; $\mathrm{BE}=$ Benevolence values; $\mathrm{UN}=$ Universalism values; $\mathrm{SD}=$ Self-direction values; $\mathrm{ST}=$ Stimulation values; $\mathrm{HE}=$ Hedonism values; $\mathrm{AC}=$ Achievement values; $\mathrm{PO}=$ Power values; $\mathrm{SE}=$ Security values.

voters, it is possible that the results presented here testify to the superiority of basic values as a measure of personality in politics.

Although the results discussed thus far demonstrate a normatively positive image of MPs, who contrary to media speculation - are more motivated by the welfare of others than themselves, the data collected here also suggest that they are more motivated than the public to control resources and to be in charge of others (Power values: $t(2,257)=7.12, \mathrm{p}<0.001$; support for Hypothesis 2 ). In representative national samples around the world, Power values have consistently received the lowest average ratings (c.2.3) on the PVQ's Likert scale of 0 (Not like me at all) to 6 (Very much 
like me) (for example, Bardi and Schwartz 2003). This is likewise the case for the ESS sample of the British public used in this article, for whom Power values are rated as least important among all basic values. However, Power values are rated by MPs as more important than Achievement, Hedonism and Tradition values, and receive an average rating among participants of 3.6.

It is possible that this difference in Power values between MPs and the public is a consequence of selection rather than self-selection. Put another way, voters may be inclined to select parliamentary candidates who exhibit Power values through associated behaviours that imply confidence and competence. To account for this alternative explanation, I conduct another series of t-tests between the ESS sample and 134 unsuccessful parliamentary candidates. Even after applying Bonferroni corrections, candidates score differently on all lower-order basic values except Achievement and Benevolence (Figure 2), and to high degrees of statistical significance. These differences run in the same direction as those reported between elected MPs and the public in Table 2, and crucially, candidates attribute much more importance to Power values than the general public $(\mathrm{t}(2,281)=8.32, \mathrm{p}<0.001)$. I suggest, therefore, that these data reflect meaningful trends in the self-selection of individuals to democratic office.

\section{RQ2: To what extent do personality characteristics such as basic values affect self-selection to elite} politics?

The comprehensive model of candidate emergence presented in Figure 1 predicts that basic values will not only capture meaningful psychological distinctions between governors and the governed, but will also affect political ambition in tandem with previously researched sociodemographic variables such as profession, education and gender (cf. Allen and Cutts 2018; Lawless 2012). To investigate the predictive power of these variables upon candidate emergence, I calculate a series of binomial logistic regressions (Table 3).

Based on earlier theoretical assumptions, variables are included sequentially to test the cumulative effect of personality (basic values), demographics (age and gender), professional skills (education and current/prior occupation) and political opportunity structures (prior experience of politics - measured here as membership of or employment in a political party or trade union). When using prior experience to proxy for political opportunity structures, it is assumed that (a) participants will be more likely to have accrued these experiences where opportunities to do so were transparent and attractive, and (b) that formal political participation will provide the contacts and knowledge necessary to secure a successful candidacy. Models 1-4 take parliamentary candidacy per se as the outcome variable, whereas Model 5 limits the dependent variable to successful candidacy. Achievement values and Hedonism values are excluded a priori on the basis that they do not reveal any significant differences between MPs and the British public (see RQ1, above), and coefficients are calculated with robust standard errors to account for heteroskedasticity in the data. All continuous variables have been rescaled to $0-1$ in order to ease interpretation.

The results presented in Table 3 indicate that basic values are strong predictors of whether someone will put themselves forward as a parliamentary candidate or even go on to become an elected MP. These effects hold even after controlling for age, gender, education, occupation and prior political experience. ${ }^{6}$ For example, Benevolence values (as a facet of Self-Transcendence values) are particularly important (Hypothesis 1). Models 4 and 5 suggest that individuals who score highest on these values - and are by implication most motivated by caring for and supporting the welfare of others - are much more likely to become an MP than those who attribute less importance to these values in their daily lives. The same is true

\footnotetext{
${ }^{6}$ Robustness checks were conducted to rule out the effects of multicollinearity in each regression model. For each value item, the tolerance levels of the other value items were well above 0.25. Similarly, the Variance Inflation Factor (VIF) statistics for each value item - as a predictor of another value item - were below 2, and thus well beneath the maximum VIF scores of 5 (e.g., Rogerson 2001) recommended in the existing literature.
} 
Table 3. Basic values and candidate emergence in the UK

\begin{tabular}{|c|c|c|c|c|c|}
\hline & \multicolumn{5}{|c|}{ Dependent variable } \\
\hline & \multicolumn{4}{|c|}{ Candidate $(\mathrm{N}=240)$} & \multirow[b]{2}{*}{$\begin{array}{l}\text { MP }(\mathrm{N}=106) \\
\text { Full model for } \\
\text { elected MPs } \\
5\end{array}$} \\
\hline & $\begin{array}{c}\text { Values only } \\
1\end{array}$ & $\begin{array}{c}\text { + Demographics } \\
2\end{array}$ & $\begin{array}{c}\text { + Professional } \\
\text { resources } \\
3\end{array}$ & $\begin{array}{c}\text { + Political } \\
\text { opportunity } \\
4\end{array}$ & \\
\hline Conformity (0-1) & $\begin{array}{l}6.389^{\star \star *} \\
(0.707)\end{array}$ & $\begin{array}{l}6.137^{\star \star \star} \\
(0.747)\end{array}$ & $\begin{array}{l}7.699 * \star \star \\
(1.026)\end{array}$ & $\begin{array}{l}7.570^{\star \star \star} \\
(1.043)\end{array}$ & $\begin{array}{l}6.244^{\star \star \star} \\
(1.027)\end{array}$ \\
\hline Tradition (0-1) & $\begin{array}{l}-4.479^{\star \star \star *} \\
(0.779)\end{array}$ & $\begin{array}{l}-5.066^{\star \star \star} \\
(0.817)\end{array}$ & $\begin{array}{l}-4.931^{\star \star \star} \\
(0.025)\end{array}$ & $\begin{array}{l}-4.840^{\star \star \star} \\
(0.963)\end{array}$ & $\begin{array}{c}-0.909 \\
(1.092)\end{array}$ \\
\hline Benevolence (0-1) & $\begin{array}{l}4.546^{\star \star *} \\
(0.833)\end{array}$ & $\begin{array}{l}5.401^{\star \star \star} \\
(0.903)\end{array}$ & $\begin{array}{l}5.422^{\star \star *} \\
(1.216)\end{array}$ & $\begin{array}{l}5.364^{\star \star \star} \\
(1.171)\end{array}$ & $\begin{array}{l}5.291^{\star \star \star} \\
(1.059)\end{array}$ \\
\hline Universalism (0-1) & $\begin{array}{l}6.058^{\star \star \star *} \\
(1.031)\end{array}$ & $\begin{array}{l}6.016^{\star \star \star} \\
(1.093)\end{array}$ & $\begin{array}{l}5.179^{\star \star \star *} \\
(1.435)\end{array}$ & $\begin{array}{l}4.877^{\star \star \star} \\
(1.404)\end{array}$ & $\begin{array}{c}1.519 \\
(1.385)\end{array}$ \\
\hline Self-Direction (0-1) & $\begin{array}{l}3.847^{\star * \star} \\
(0.803)\end{array}$ & $\begin{array}{l}3.360^{\star * *} \\
(0.863)\end{array}$ & $\begin{array}{l}2.687^{\star} \\
(1.056)\end{array}$ & $\begin{array}{l}2.644^{\star} \\
(1.032)\end{array}$ & $\begin{array}{c}-1.156 \\
(1.21)\end{array}$ \\
\hline Stimulation $(0-1)$ & $\begin{array}{l}5.986^{\star \star \star} \\
(0.746)\end{array}$ & $\begin{array}{l}5.869^{\star \star \star} \\
(0.774)\end{array}$ & $\begin{array}{l}6.568^{\star \star \star} \\
(1.113)\end{array}$ & $\begin{array}{l}6.642^{\star \star \star} \\
(1.128)\end{array}$ & $\begin{array}{l}3.548^{\star \star \star} \\
(1.051)\end{array}$ \\
\hline Power (0-1) & $\begin{array}{l}8.841^{\star \star \star} \\
(0.832)\end{array}$ & $\begin{array}{l}8.987^{\star \star \star} \\
(0.849)\end{array}$ & $\begin{array}{l}9.191^{\star \star \star} \\
(1.204)\end{array}$ & $\begin{array}{l}9.060^{\star \star \star} \\
(1.219)\end{array}$ & $\begin{array}{l}5.916^{\star \star \star} \\
(1.158)\end{array}$ \\
\hline Security (0-1) & $\begin{array}{c}-1.848^{\star \star} \\
(0.697)\end{array}$ & $\begin{array}{c}-1.860^{\star \star} \\
(0.753)\end{array}$ & $\begin{array}{c}-1.601^{\star} \\
(1.038)\end{array}$ & $\begin{array}{c}-1.866 \\
(1.022)\end{array}$ & $\begin{array}{c}-0.609 \\
(1.021)\end{array}$ \\
\hline Gender (Male) & & $\begin{array}{l}1.104^{\star \star \star} \\
(0.195)\end{array}$ & $\begin{array}{l}1.148^{\star \star \star} \\
(0.251)\end{array}$ & $\begin{array}{l}1.121^{\star \star \star} \\
(0.251)\end{array}$ & $\begin{array}{c}0.463 \\
(0.298)\end{array}$ \\
\hline Age $(0-1)$ & & $\begin{array}{l}1.482^{\star * *} \\
(0.386)\end{array}$ & $\begin{array}{l}3.028^{\star \star \star *} \\
(0.631)\end{array}$ & $\begin{array}{l}2.978^{* \star *} \\
(0.642)\end{array}$ & $\begin{array}{l}2.556^{\star *} \\
(0.803)\end{array}$ \\
\hline Education & & & $\begin{array}{l}0.920^{\star \star \star} \\
(0.108)\end{array}$ & $\begin{array}{l}0.916^{\star \star \star} \\
(0.11)\end{array}$ & $\begin{array}{l}0.884^{\star \star \star} \\
(0.125)\end{array}$ \\
\hline Brokerage & & & $\begin{array}{l}1.525^{\star \star *} \\
(0.324)\end{array}$ & $\begin{array}{l}1.556^{\star * *} \\
(0.329)\end{array}$ & $\begin{array}{l}3.264^{\star * *} \\
(0.606)\end{array}$ \\
\hline Charity/'Helping' & & & $\begin{array}{l}1.171^{\star *} \\
(0.404)\end{array}$ & $\begin{array}{l}1.219^{\star *} \\
(0.412)\end{array}$ & $\begin{array}{l}2.515^{\star \star \star} \\
(0.68)\end{array}$ \\
\hline $\begin{array}{l}\text { Manual/ } \\
\text { Administrative }\end{array}$ & & & $\begin{array}{l}-2.475^{\star \star \star} \\
(0.459)\end{array}$ & $\begin{array}{c}-2.506^{\star \star \star} \\
(0.483)\end{array}$ & $\begin{array}{c}-0.096 \\
(0.753)\end{array}$ \\
\hline Public Sector & & & $-1.224^{\star \star \star}$ & $-1.181^{\star \star}$ & 0.595 \\
\hline Professional & & & $(0.369)$ & $(0.373)$ & $(0.667)$ \\
\hline Prior Experience & & & & $\begin{array}{l}0.952^{* * *} \\
(0.261)\end{array}$ & $\begin{array}{c}0.719^{\star} \\
(0.294)\end{array}$ \\
\hline Constant & $\begin{array}{c}-19.023^{* * *} \\
(2.096)\end{array}$ & $\begin{array}{c}-20.123^{\star * \star} \\
(2.208)\end{array}$ & $\begin{array}{c}-24.248^{\star * *} \\
(3.015)\end{array}$ & $\begin{array}{c}-24.366^{\star * \star} \\
(3.031)\end{array}$ & $\begin{array}{c}-20.520^{\star \star \star} \\
(3.271)\end{array}$ \\
\hline Observations & 2,388 & 2,373 & 2,156 & 2,156 & 2,156 \\
\hline Cox \& Snell $\mathrm{R}^{2}$ & 0.249 & 0.269 & 0.397 & 0.401 & 0.201 \\
\hline Log Likelihood & -447.566 & -418.354 & -246.343 & -239.131 & -198.849 \\
\hline Akaike Inf. Crit. & 913.132 & 858.709 & 524.685 & 512.261 & 431.697 \\
\hline
\end{tabular}

Note: the addition of control variables for age and gender makes only a small substantive difference to the overall effects of basic values on candidate emergence (see Models 1 and 2 in Table 3). The Appendix shows that the same is true when the full model (Model 5) is run for the subsample of elected MPs minus controls for age. To help protect the anonymity of participants, age has been redacted from the dataset deposited on Harvard Dataverse. ${ }^{*} p<0.05 ;{ }^{* *} p<0.01 ;{ }^{* \star *} p<0.001$

of Stimulation values, indicating that those most motivated by excitement, novelty and challenge are more likely to enter elected office. By contrast, Conservation values such as Tradition and Security are negative predictors of candidate emergence, although these effects drop out in Model 5. Power values (as a facet of Self-Enhancement values) also emerge as strong predictors of being a parliamentary candidate or an elected MP.

To aid the interpretation of these results, the average marginal effects for all independent variables in Models 4 and 5 are illustrated in Figure 3 along with 95 per cent confidence intervals. These effects indicate that basic values have a significant impact on who runs for parliamentary office (or does so successfully) that is equal to or larger than the effects of demographic or socioeconomic variables. Given that basic values have been rescaled to $0-1$, these results reflect the 


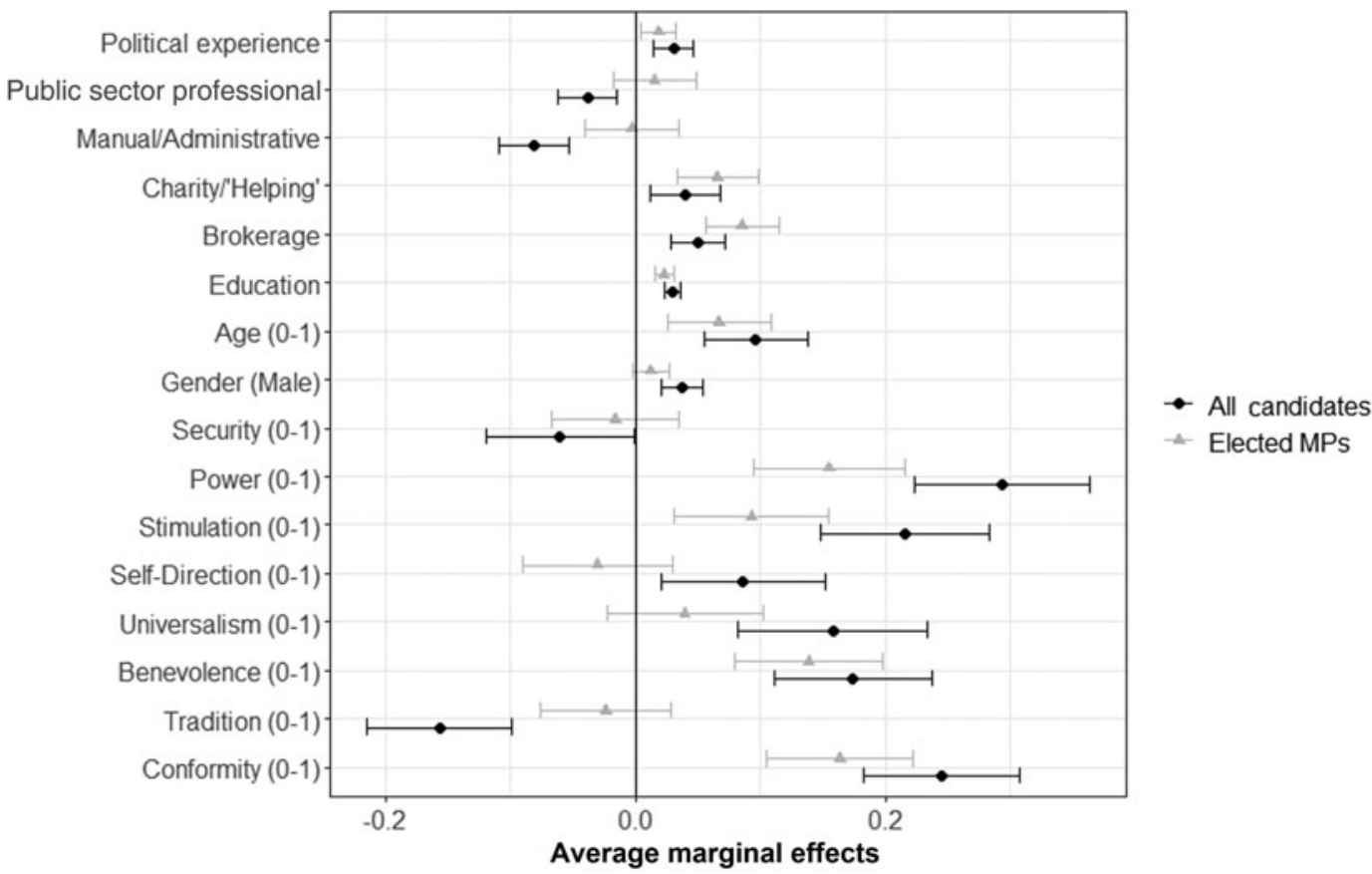

Figure 3. Average marginal effects for predictors of candidate emergence in the United Kingdom Note: 'Brokerage' = occupations such as law, finance and the media; 'Charity/'Helping' = occupations in the third sector, Church and the emergency services; 'Public Sector Professional' = highly skilled public sector occupations in education, health care and the civil service; 'Manual/Administrative' = traditional blue-collar occupations in sectors such as construction or office jobs related to secretarial work; 'Education' = five-factor variable including no qualifications, apprenticeship or vocational qualification, A-Levels, undergraduate degree, postgraduate degree.

change in probability of each outcome variable across the whole range of scores for each value in the samples used. For example, participants scoring highest for Benevolence values were, on average, 17 per cent more likely to be a parliamentary candidate and 13 per cent more likely to be an elected MP than those attributing the least importance to that value factor. However, Power values exert the strongest effects in these models. Participants scoring highest for Power values in these samples were, on average, 29 per cent more likely to be a parliamentary candidate. In Model 5, Conformity values have equally large effects (AME $=0.16$ ). This is a theoretically ambiguous result, given that Conformity values relate to socially conservative and subordinating predispositions that are antithetical to the derivative goals of other significant Self-Enhancement and Openness to Change values.

As anticipated earlier in this article, political opportunity structures and socio-economic resources appear to be helpful, yet insufficient, for explaining successful candidate emergence. The pseudo r-squared scores reported in Table 3, for example, show that the amount of variation in the outcome variable explained by the predictors increases in each model cumulatively. The AIC and log-likelihood fit statistics also improve with each model. That said, basic values jointly account for 25 per cent of the variation in the outcome variable (being a parliamentary candidate), which is more than any other predictor tested here. These results support those of Whiteley and Seyd (2002) in demonstrating that when data confront theory on the topic of highintensity participation in politics, there may be more than one correct answer. As per the cumulative narrative represented in Figure 1, future studies should seek to synthesize the conceptual and empirical wisdom of multiple approaches. 


\section{Discussion}

In this article, I set out to explore the psychological nature of candidate emergence in the United Kingdom. Using a unique dataset on the basic values of 106 MPs and 134 unsuccessful parliamentary candidates, I find that (a) elected and aspiring national politicians in the UK are different in their psychological composition to the general public and (b) basic values act as powerful internal criteria for self-selection to elite politics. Going beyond previous work on the demographic and socio-economic predictors of political ambition (Allen and Cutts 2018; Lawless 2012), the data presented in this article suggest that aspirations towards elected office - and indeed success in fulfilling those aspirations - relate strongly to certain psychological backstops.

On the one hand, the strong associations found here between Openness to Change values and candidate emergence are indicative of the creative, problem-solving nature of the job, as opposed to more programmatic and risk-averse professions that tend to attract individuals high in Conservation values (Arieli and Tenne-Gazit 2017). The predictive power of Stimulation values, in particular, suggests that this link is more affect oriented than cognitive: it may be the desire for excitement, impulsiveness and diversity that attracts people to parliamentary politics. On the other hand, my data complement previous research demonstrating the link between Self-Transcendence values and 'calling' professions (Gandal et al. 2005). It would appear that citizens attracted to political office have an intense calling orientation and may see elected politics as a vehicle through which to fulfil socially valuable work and obtain some level of self-actualization. At the same time, the intense combination of prosocial public service and conflictual, hierarchical, even resource-driven party politics appears to attract people with a relatively strong orientation towards Power values.

From a normative and empirical standpoint, these results should be interpreted carefully and, in the first instance, holistically. When MPs' basic values are assessed as a whole, then the results presented in this article are indicative of the democratic elitism previously researched in the US (for example, McCloskey 1964; Peffley and Rohrschneider 2003). Put simply, a highly liberal political elite (strongly motivated by Self-Transcendence and Openness to Change values) represent a comparatively authoritarian public (more motivated by Conservation values). Charges related to the flawed characters and self-serving nature of the political class do not appear, then, to withstand empirical scrutiny. Although the data do indicate that MPs score higher than the public for Power values, implying a greater desire to seek and control resources, the 'motivational differences between [basic] values can be seen as continuous rather than discrete' (Schwartz 2014, 247). Therefore, MPs' scores for Power values must be understood against their conflict with opposing values such as Universalism, Benevolence and Self-Direction (on which MPs score more positively overall).

For students of anti-politics (Clarke et al. 2018; Jennings, Stoker and Twyman 2016) and 'stealth populism' (Stoker and Hay 2017) in the UK and abroad - for whom popular perceptions of politicians' personal qualities are key to growing and potentially dangerous forms of political dissent and disengagement - the findings in this article arguably supplement and challenge their research. For example, people who give high priority to Self-Transcendence and Openness to Change values tend to prefer and promote policies that they believe will extend and defend individual freedoms (Piurko, Schwartz and Davidov 2011). If one assumes a normative position that (a) democracy is preferable to other political systems and that (b) it is best protected by those who are motivationally aligned to its core principles, then the psychological (self-)selection of MPs discovered in this study is a positive outcome and largely contradicts popular narratives of selfinterested politicians.

The relevance of the data collected and analysed for this article may, however, centre on the extent to which politicians act upon the incongruent motivations expressed by Self-Transcendence and Self-Enhancement values. If MPs primarily act upon Benevolence and Universalism values in their representative roles - or have the freedom to do so - then public 
fears about self-serving elites are unfounded or at least exaggerated. If in fact MPs act more often than not upon Power values, then scholars might conclude that public apathy and discontent towards politicians is grounded in impressively perceptive psychological judgements that go beyond media negativity bias. Given that values are often activated by immediate situations (Bardi and Schwartz 2003; Verplanken and Holland 2002), future studies might conduct a more detailed analysis of the Westminster environment and its dominant behavioural stimuli. Such studies might, then, ascertain whether MPs' general commitment to the motivational goals of Self-Transcendence values are activated by comparison to the relative importance they assign to Power values. Experimental surveys and ethnographic research might also assess the extent to which MPs are able to withstand institutional cues and, instead, reconceptualize the political environment proactively in line with their most important values.

One noticeable anomaly in the data is the positive association between Conformity values and being an MP $(\mathrm{r}(2,258)=0.047, \mathrm{p}<0.05$; see also Tables 2 and 3$)$. This result is antithetical to the assumptions of the Schwartz taxonomy and its sinusoidal structure. Conceptually, Conformity values are conceived in the Schwartz taxonomy as comprising two related subtypes: the first is interpersonal (maintaining harmonious social relations) and the second is compliance (conforming to expectations). Empirical evidence suggests that these two subtypes are readily distinguishable: the compliance items tend to co-vary with Security values, while the interpersonal items share stronger relationships with Benevolence values (Beierlein et al. 2012; Schwartz et al. 2012). I anticipate that the ratings given to Conformity values by politicians in this study who also score much higher than the public on Benevolence values - are inflated by participants' heightened sensitivity to its interpersonal elements. Inter-item correlations provide preliminary support for this assumption. Modest correlations between the Conformity items answered by MPs $(\mathrm{r}(238)=0.315, \mathrm{p}<0.001)$ are almost matched by the correlation between the interpersonal item and one of the Benevolence items $(\mathrm{r}(238)=0.281, \mathrm{p}<0.001)$. By contrast, the compliance item for Conformity values shares weaker associations with both Benevolence items ( $\mathrm{r}(238)=$ $0.159, \mathrm{p}<0.05 ; \mathrm{r}(238)=0.213, \mathrm{p}<0.001)$.

At the same time, the differences in these correlations are not particularly large. Far from being a methodological issue with the Schwartz taxonomy of basic values (or measures thereof), there may be a more obvious explanation grounded in the nature of British political traditions. For example, it is possible that candidates who attribute importance to Conformity values, and thus exhibit a propensity towards teamwork, are also more likely to be successful in party-based electoral politics. At the constituency level, single-member plurality systems like the UK do not provide voters with intraparty choice. As such, there are few incentives for voters (or partisans at the very least) to prioritize individual candidates over the collective movement. Candidates must therefore learn to work with, persuade, and collaborate with others in their local, regional or national party frameworks whose opinions or behaviours they do not always like or agree with. Candidates who prioritize interpersonal relationships and lean towards appeasing others may have a natural advantage in this game.

This study suffers from a number of limitations and it is important to be open about these so as to assist future research in this area. First, the comparison of data from two different measurement tools (the PVQ-21 used by the ESS and the TwIVI taken by MPs and candidates) is not ideal. Although the PVQ-21 and the TwIVI are both derived from the same theoretical framework, ten of their item descriptors differ. While they still share extremely similar properties in terms of internal and external validity (see Sandy et al. 2017), it was not possible to use confirmatory factor analysis to assess measurement invariance between the data collected from politicians and the public. Future studies should therefore seek to replicate these results using identical survey measures administered under identical test conditions. This does, however, pose a significant hurdle to researchers working with time-poor and highly inaccessible populations of political elites. Secondly, the data operationalized to explain candidate emergence in this article cannot necessarily account for the confounding effects exerted by party selectorates or the preferences 
of different constituency-level electorates. Thirdly, future studies of political ambition may seek to employ more appropriate measures of opportunity structures. While I used participants' political experience as a proxy in the logits reported in Table 3, this may be a weak substitute for more precise rational choice indicators (for examples, see Chapter 3 in Whiteley and Seyd 2002).

This article did not set out to build a sympathetic counternarrative about politicians, but rather to test unfounded psychological claims that underpin popular disillusionment with democratic politics and to clarify the contested and amorphous nature of related academic debates. Psychologically speaking, the gap between 'them and us' is considerable, but these results are not necessarily negative depending on the subjective understanding of democratic leadership brought to bear upon them. Indeed, a rich literature on the 'mandate-independence' controversy (Pitkin 1967) and more recently a 'trap' account (Medvic 2013) of politics makes it clear that 'electors want their leaders to be just like them but also much better than them' (Kane and Patapan 2012, 44). In a contemporary climate characterized by a populist 'race to the bottom' in terms of both political rhetoric and policy responses, I argue that our perceptions of politicians' moral rectitude may be grossly distorted. We may, therefore, need to give more urgent attention to fundamentally systematic aspects of our political system and its culture, including the democratic imperative of the press, the adequacy of our political institutions and their accountability mechanisms, and the transparency of party-political hierarchies and career paths.

Supplementary material. Replication data sets are available in Harvard Dataverse at: https://doi.org/10.7910/DVN/ CMKMGF and online appendices at: https://doi.org/10.1017/S0007123419000814.

\section{References}

Allen P (2018) The Political Class: Why it Matters who our Politicians Are. Oxford: Oxford University Press.

Allen P and Cairney P (2015) What do we mean when we talk about the 'political class'? Political Studies Review 2015, 1-10. Allen P and Cutts D (2018) An analysis of political ambition in Britain. The Political Quarterly 89(1), 73-81.

Arieli S, Sagiv L and Cohen-Shalem E (2016) Values in business schools: the role of self-selection and socialization. Academy of Management Learning \& Education 15(3), 493-507.

Arieli S and Tenne-Gazit $\mathbf{O}$ (2017) Values and behaviour in a work environment: taking a multi-level perspective. In Roccas S and Sagiv L (eds), Values and Behaviour: Taking A Cross Cultural Perspective. New York: Springer International Publishing, pp. 115-141.

Bardi A and Schwartz SH (2003) Values and behaviour: strength and structure of relations. Personality and Social Psychology Bulletin 29(10), 1207-1220.

Beierlein C et al. (2012) Testing the discriminant validity of Schwartz' Portrait Value Questionnaire items - a replication and extension of Knoppen and Saris (2009). Survey Research Methods 6, 25-36.

Best H (2011) Does personality matter in politics? Personality factors as determinants of parliamentary recruitment and policy preferences. Comparative Sociology 10, 928-948.

Caprara GV, Vecchione M and Schwartz S (2009) Mediational role of values in linking personality traits to political orientation. Asian Journal of Social Psychology 12, 82-94.

Caprara GV et al. (2010) Personality foundations of ideological divide: a comparison of women members of parliament and women voters in Italy. Political Psychology 31, 739-762.

Caprara GV and Silvester J (2018) The personality attributes of political elites. In Best H, Daloz JP and Hoffman-Lange U (eds), Palgrave Handbook of Political Elites. London: Palgrave.

Clarke N et al. (2018) The Good Politician: Folk Theories, Political Interaction, and the Rise of Anti-Politics. Cambridge: Cambridge University Press.

Cohen S (2011) Folk Devils and Moral Panics. Abingdon: Taylor and Francis Ltd.

Corbett J (2015) Diagnosing the problem of anti-politicians: a review and an agenda. Political Studies Review 14(4), 534-543.

Daniel E et al. (2015) Values and helping behaviour: a study in four cultures. International Journal of Psychology 50(3), 186192.

Dietrich BJ et al. (2012) Personality and legislative politics: the Big Five trait dimensions among US state legislators. Political Psychology 33(2), 195-210.

Easton D (1965) A Systems Analysis of Political Life. New York: Wiley.

ESS Round 7: European Social Survey Round 7 Data (2014) Data file edition 2.1. NSD - Norwegian Centre for Research Data, Norway - Data Archive and distributor of ESS data for ESS ERIC.

Flinders M (2012) Defending Politics: Why Democracy Matters in the Twenty-First Century. Oxford: Oxford University Press. 
Gandal N, et al. (2005) Personal value priorities of economists. Human Relations 58(10), 1227-1252.

Greenstein F (1992) Can personality and politics be studied systematically? Political Psychology 13(1), 105-128.

Hair J et al. (2006) Multivariate Data Analysis. Upper Saddle River, NJ: Pearson/Prentice Hall Inc.

Hanania R (2017) The personalities of politicians: a Big Five study of American legislators. Personality and Individual Differences 108, 164-167.

Hitlin S (2003) Values as the core of personal identity: drawing links between two theories of self. Social Psychology Quarterly 66(2), 118-137.

Jennings W, Stoker G and Twyman J (2016) The dimensions and impact of political discontent in Britain. Parliamentary Affairs 69, 876-900.

Kane J and Patapan H (2012) The Democratic Leader: How Democracy Defines, Empowers, and Limits Its Leaders. Oxford: Oxford University Press.

Kazee, T. A. (1994) The emergence of congressional candidates. In T. Kazee (ed.), Who Runs for Congress? Ambition, Context, and Candidate Emergence. Washington, DC: Congressional Quarterly.

Lawless J (2012) Becoming A Candidate: Political Ambition and the Decision to Run for Office. Cambridge: Cambridge University Press.

Lawless J and Fox RL (2005) It Takes A Candidate: Why Women Don't Run for Office. New York: Cambridge University Press.

Lawless J and Fox RL (2010) It Still Takes A Candidate: Why Women Don't Run for Office. New York: Cambridge University Press.

Maestas C, et al. (2006) When to risk it? Institutions, ambitions, and the decision to Run for the U.S. House. American Political Science Review 100(2), 195-208.

McCloskey H (1964) Consensus and ideology in American politics, American Political Science Review 58, 361-382.

Medvic SK (2013) In Defence of Politicians: The Expectations Trap and its Threat to Democracy. London: Routledge.

Moncrief GF, Squire P and Jewell ME (2001) Who Runs for the Legislature? Upper Saddle River, NJ: Prentice Hall.

Nørgaard AS and Klemmensen R (2018) The personalities of Danish MPs: trait- and aspect- level differences. Journal of Personality. doi: 10.1111/jopy.12388.

Norris P (2011) Democratic Deficits. Cambridge: Cambridge University Press.

Parks-Leduc L, Feldman G and Bardi A (2015) Personality traits and personal values: a meta-analysis. Personality and Social Psychology Review 19(1), 3-29.

Peffley M and Rohrschneider R (2003) Democratization and political tolerance in seventeen countries: a multilevel model of democratic learning. Political Research Quarterly 56(3), 243-257.

Piurko Y, Schwartz SH and Davidov E (2011) Basic personal values and the meaning of left-right political orientations in 20 countries. Political Psychology 32, 537-561.

Pitkin HF (1967) The Concept of Representation. Berkeley: University of California Press.

Putnik DL and Bornstein MH (2016) Measurement invariance conventions and reporting: the state of the art and future directions for psychological research. Developmental Review 41, 71-90.

Roccas S et al. (2014) Integrating content and structure aspects of the self: traits, values, and self-improvement. Journal of Personality 82(2), 144-157.

Rogerson PA (2001) Statistical Methods for Geography. London: Sage.

Sagiv L (2002) Vocational interests and basic values. Journal of Career Assessment 10(2), 233-257.

Sagiv L and Roccas S (2017) What personal values are and what they are not: taking a cross-cultural perspective. In Roccas S and Sagiv L (eds), Values and Behaviour: Taking A Cross Cultural Perspective. New York: Springer International Publishing, pp. 3-13.

Sandy CJ et al. (2017) The development and validation of brief and ultra-brief measures of values. Journal of Personality Assessment 99, 545-555.

Schlesinger JA (1966) Ambition and Politics: Political Careers in the United States. Chicago, IL: Rand McNally and Co.

Schwartz S (1992) Universals in the content and structure of values: theoretical advances and empirical tests in 20 countries. Advances in Experimental Psychology 25, 1-65.

Schwartz S (2010) Basic values. How they motivate and inhibit prosocial behaviour. In Mikulincer M and Shaver PR (eds), Prosocial Motives, Emotions, and Behaviour: The Better Angels of our Nature. Washington, DC: American Psychological Association, pp. 221-241.

Schwartz S (2014) Functional theories of human values: comment on Gouveia, Milfont, and Guerra (2014). Personality and Individual Differences 68, 247-249.

Schwartz S, Caprara GV and Vecchione M (2010) Basic personal values, core political values, and voting: a longitudinal analysis. Political Psychology 31(3), 421-452.

Schwartz S et al. (2012) Refining the theory of basic individual values. Journal of Personality and Social Psychology 103(4), 663-688.

Schwartz SH (2003) A proposal for measuring value orientations across nations. Questionnaire Package of ESS, 259-290.

Schwartz SH (2005) Robustness and fruitfulness of a theory of universals in individual human values. In Tamayo A and Porto JB (eds), Values and Behaviour in Organizations. Petrópolis: Vozes, pp. 56-95. 
Schwartz SH et al. (2001) Extending the cross-cultural validity of the theory of basic human values with a different method of measurement. Journal of Cross-Cultural Psychology 32(5), 519-542.

Scott C and Medeiros M (2019) Personality and political careers: What personality types are likely to run for office and get elected? Personality and Individual Differences. doi.org/10.1016/j.paid.2019.109600.

Stoker G and Hay C (2017) Understanding and challenging populist negativity towards politics: the perspectives of British citizens. Political Studies 65(1), 4-23.

Twenge JM et al. (2007) Social exclusion decreases prosocial behaviour. Journal of Personality and Social Psychology 92(1), 56-66.

Verplanken B and Holland RW (2002) Motivated decision making: effects of activation and self-centrality of values on choices and behaviour. Journal of Personality and Social Psychology 82(3), 434-447.

Weinberg J (2019) The winner takes it all? A psychological study of political success among UK Members of Parliament. Parliamentary Affairs. doi.org/10.1093/pa/gsz017.

Weinberg J (2020) "Replication Data for: 'Who Wants to be a Politician? Basic Human Values and Candidate Emergence in the United Kingdom.”, https://doi.org/10.7910/DVN/CMKMGF, Harvard Dataverse, V1, UNF:6:uGxiizsobq0CNXhlKeJkOA== [fileUNF]

Whiteley P et al. (2016) Why do voters lost trust in governments? Public perceptions of government honesty and trustworthiness in Britain, 2000-2013. British Journal of Politics and International Relations 18(1), 234-254.

Whiteley P and Seyd P (2002) High Intensity Participation: The Dynamics of Party Activism in Britain. Ann Arbor: University of Michigan Press.

Wyatt $\mathbf{M}$ and Silvester J (2018) Do voters get it right? A test of the ascription-actuality trait theory of leadership with political elites. The Leadership Quarterly 29(5), 609-621.

Zaccaro SJ (2007) Trait-based perspectives of leadership. American Psychologist 62(1), 6-16.

Cite this article: Weinberg J (2021). Who Wants To Be a Politician? Basic Human Values and Candidate Emergence in the United Kingdom. British Journal of Political Science 51, 1565-1581. https://doi.org/10.1017/S0007123419000814 